\title{
Ultrastructural localization of gamma amino butyric acid immunoreactivity in $B$ cells of the rat pancreas
}

\author{
D.J. Garry, R. L. Sorenson and H.D. Coulter \\ Department of Cell Biology and Neuroanatomy, University of Minnesota, Minneapolis, Minnesota, USA
}

Summary. The purpose of this study was to determine the ultrastructural localization of gamma amino butyric acid (GABA) within the $B$ cell of isolated rat islets, particularly with respect to the $B$ cell secretion granules. GABA immunoreactivity was localized ultrastructurally, with colloidal gold, in the B cells and absent in the A cells and D cells. Quantitative analysis of the colloidal gold particle distribution in the $\mathrm{B}$ cell revealed $29.5 \pm 5.2$ gold particles $/ \mu \mathrm{m}^{2}$ in the nuclei, $29.3 \pm-$ 6.9 gold particles $/ \mu \mathrm{m}^{2}$ in the mitochondria and $4.9 \pm 1.0$ gold particles $/ \mu \mathrm{m}^{2}$ in the secretion granules. Particle density in the remainder of the cytoplasm was $41.9 \pm 4.1$ particles $/ \mu \mathrm{m}^{2}$. The paucity of gamma amino butyric acid in the B cell secretion granules differs from observations on gamma amino butyric acidergic neurons, where there is an accumulation of gamma amino butyric acid within the neurosecretory vesicles. These findings indicate that if gamma amino butyric acid is released from the islet, then it is by a nongranular mechanism. In addition, the results are compatible with the hypotheses that gamma amino butyric acid within the $B$ cell functions in the regulation of insulin biosynthesis, and/or functions as an alternative energy source for the B cell through the gamma amino butyric acid shunt.

Key words: GABA, insulin, immunohistochemistry, islet of Langerhans, electron microscopy, Lowicryl K4M.

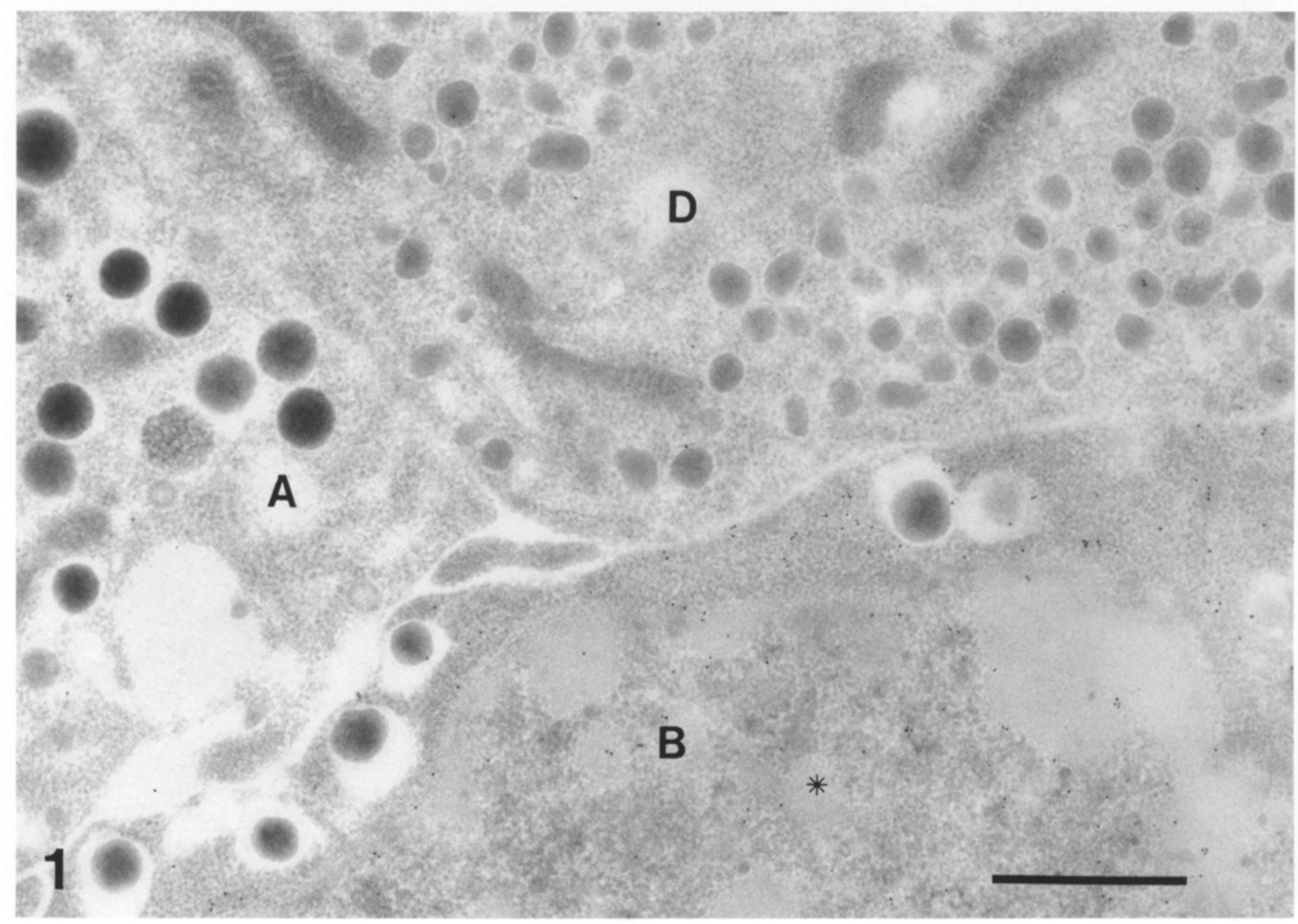

Fig. 1. Ultrastructural localization of gamma amino butyric acid (GABA) in isolated islets: A silver Lowicryl K4M section, immunohistochemically stained with $1 / 50,000 \mathrm{GABA}$ R10B antiserum and labeled with $1 / 20$ goat anti-rabbit IgG colloidal gold $10 \mathrm{~nm}$ particles. Immunoreactive GABA is localized to the extragranular and nuclear (*) compartments of the B cell and absent from the A and D cells. Magnification X33,184. $\mathrm{Bar}=0.5 \mu \mathrm{m}$ 


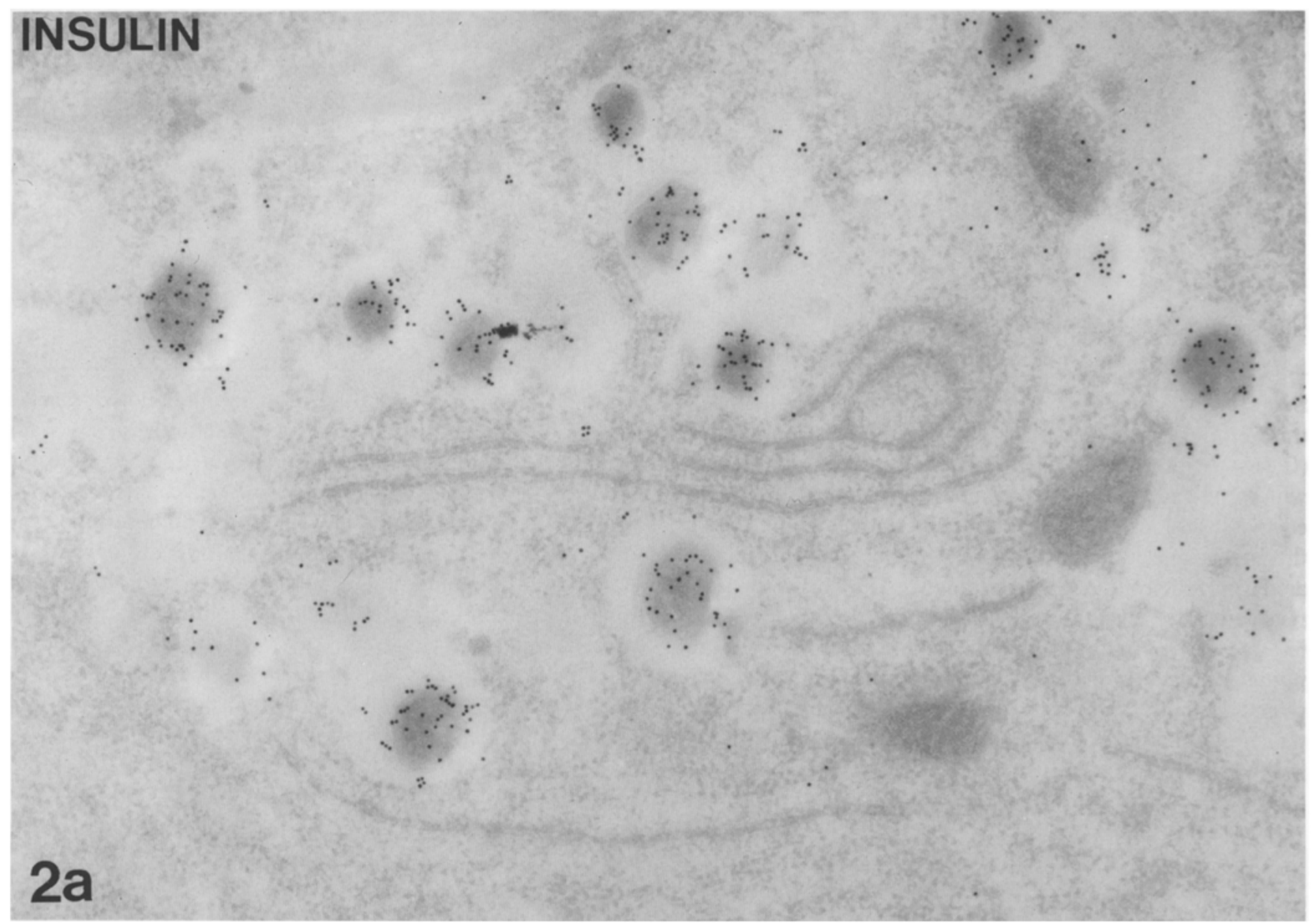

\section{GABA}

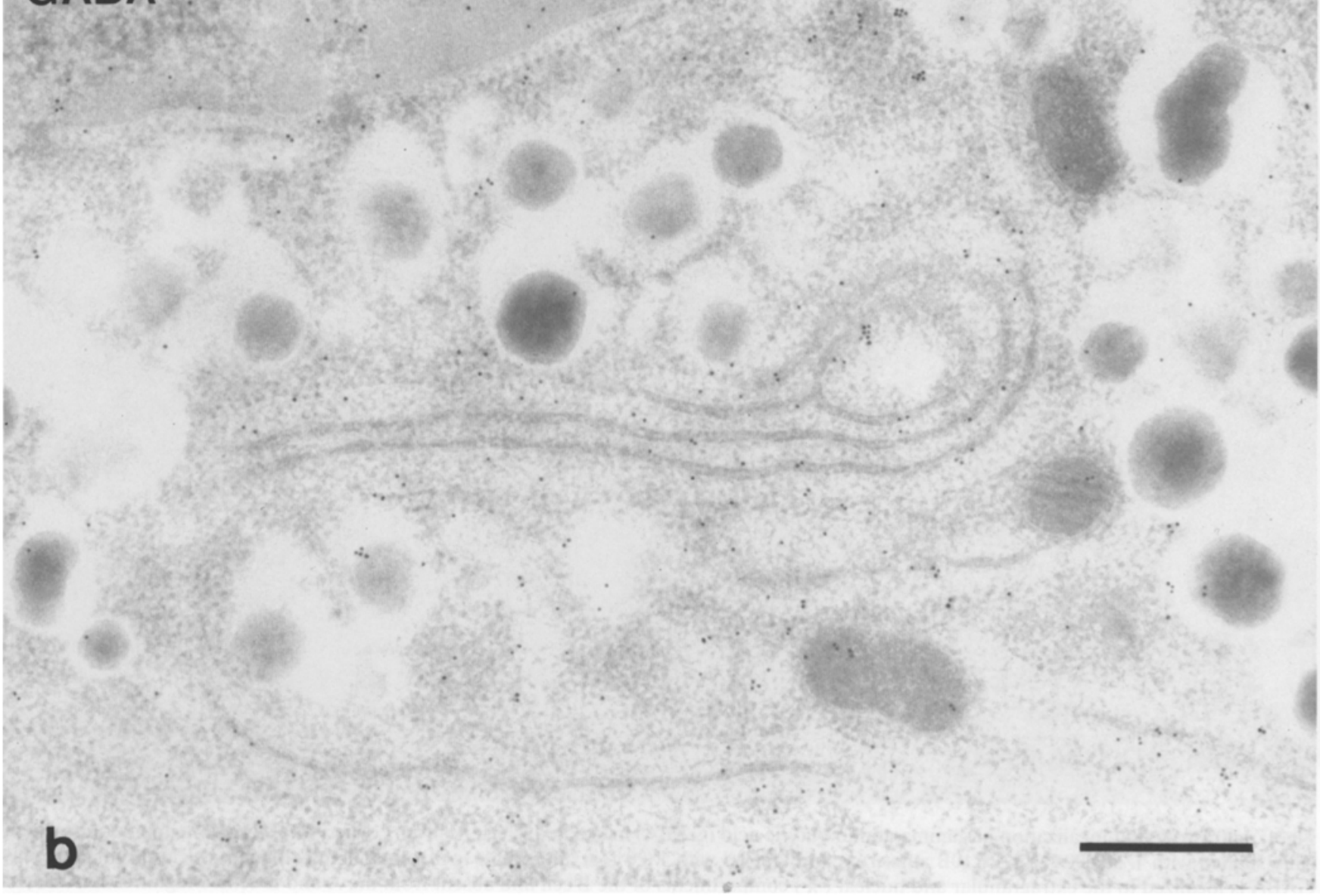




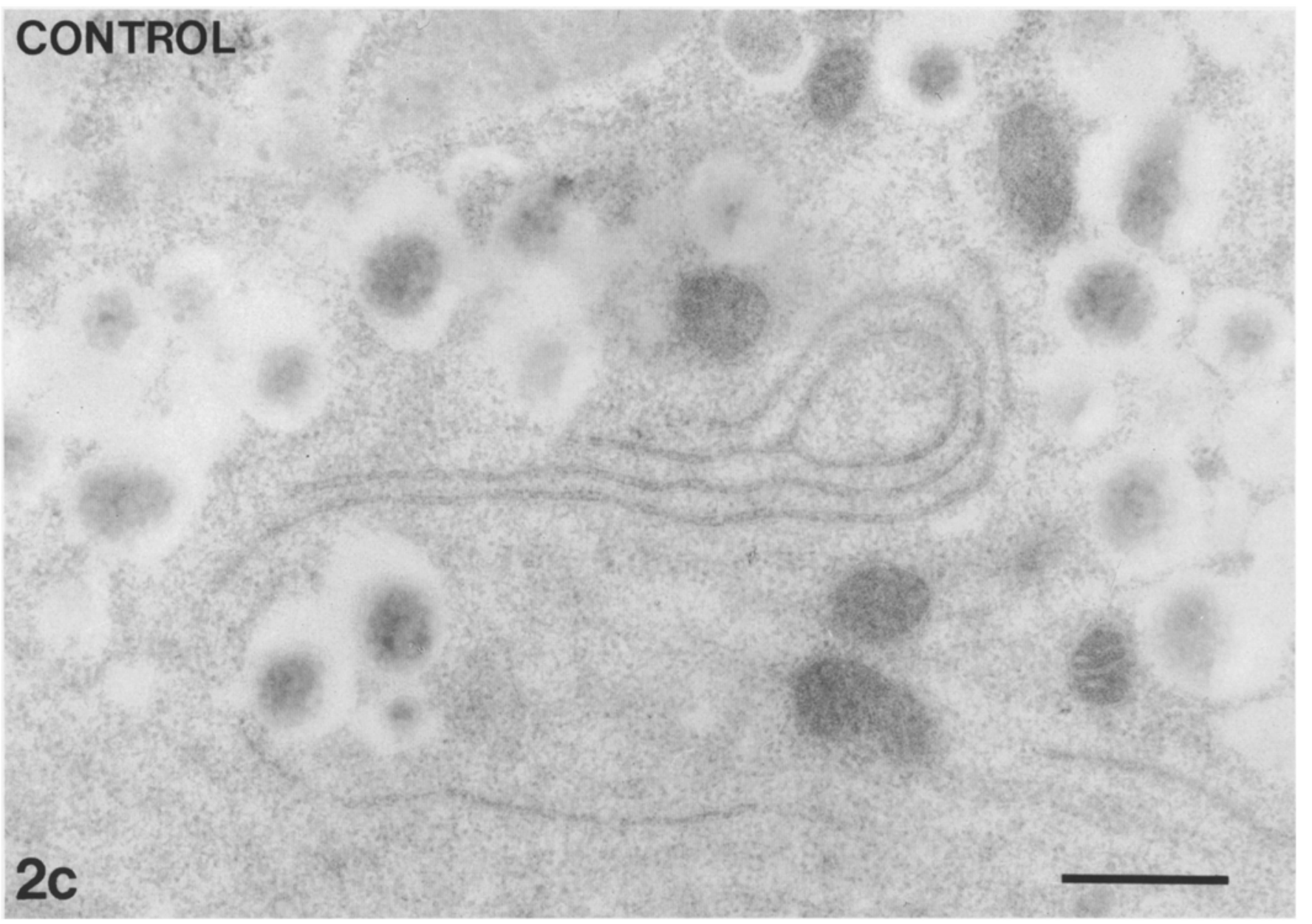

Fig. 2a-c. Ultrastructural localization of insulin, GABA and an absorption control for GABA from a representative islet B cell: serial sections of a B cell were immunohistochemically stained (using colloidal gold) with either (a) $1 / 5,000$ insulin antibody, (b) $1 / 50,000 \mathrm{GABA}$ antibody or (c) $1 / 50,000 \mathrm{GABA}$ antiserum preabsorbed with $10 \mu \mathrm{g} / \mathrm{ml}$ of the GABA immunogen (GABA conjugated to bovine serum albumin). Whereas insulin immunoreactivity is accumulated in the secretion granules, GABA is notably deficient; GABA is abundant in the cytoplasm, and present in the mitochondria and nucleus. Absorption control for specific staining of GABA antiserum reveals an absence of labeling. Magnification $\mathrm{X} 45,216 . \mathrm{Bar}=0.5 \mu \mathrm{m}$

Gamma amino butyric acid (GABA) concentrations, equivalent to those found in the central nervous system, have been measured in the pancreatic islets [1, 2]. Within the islet, GABA enzyme immunoreactivity (L-glutamate decarboxylase, E.C.4.1.1.15, and GABA- $\alpha$-ketoglutarate transaminase, E.C.2.6.1.19) and more recently, GABA immunoreactivity, have been shown to be restricted to the islet B cells [3-5]. Since the subcellular distribution of GABA is pertinent to questions regarding its function in cells containing high concentrations of GABA, then it is important to determine the ultrastructural localization of GABA.

Electron microscopic immunohistochemical studies of GABAergic neurons indicate that GABA is found in nuclei, mitochondria, cytoplasm, and accumulated in neurosecretory vesicles $[6,7]$. The accumulation of GABA within neurosecretory vesicles is compatible with its role as a neurotransmitter [7].

Although the function of GABA in the islet $B$ cell remains unclear, there is evidence that GABA can inhibit somatostatin secretion from the D cells $[3,8,9]$ and that it stimulates insulin biosynthesis [10]. A role for GABA as an energy source via the GABA shunt has also been proposed [4]. The purpose of the present study was to determine the ultrastructural immunolocalization of GABA within the B cell.

\section{Materials and methods}

Pancreatic islets were isolated from 150-200g male Sprague Dawley rats (Holtzman, Madison, Wisc, USA) by a modification [11] of the method of Lacy and Kostianovsky [12]. The tissue was immersion fixed with cold $4 \%$ paraformaldehyde, $0.3 \%$ glutaraldehyde in $0.1 \mathrm{~mol} / 1$ Sorensen's phosphate buffer. The following day the tissue was dehydrated in a graded series of ethanol, infiltrated and embedded in Lowicryl K4M (Polysciences, Warrington, PA, USA) according to the protocol of Roth et al [13]. Lowicryl K4M was chosen as the embedding media for this study because it was reported to yield better structural preservation, an improved preservation of antigenicity and significantly lower background labelling [13-15]. Serial sections with silver interference color were cut, mounted on unsupported 700 mesh nickel grids (Polaron, Watford, Herts, England) and processed for immunohistochemistry.

Sections were immersed in Tris buffer ( $\mathrm{pH} 7.2$ ) containing $2 \%$ ovalbumin for $8 \mathrm{~h}$ to decrease the nonspecific binding, and then transferred to the primary antisera [(either $1 / 50,000$ rabbit anti-GABA se- 
rum (R10B; provided by Dr. B. E. Maley), or 1/5,000 guinea pig antiinsulin serum (AIS-GP, Dr. R. L. Sorenson) [16]]. The sections were incubated in the primary antisera for $4 \mathrm{~h}$, rinsed, incubated with $1 / 20$ goat anti-rabbit IgG tagged with $10 \mathrm{~nm}$ colloidal gold particles (Janssen Life Sciences, Beerse, Belgium) for $1 \mathrm{~h}$ and stained with 7.5\% uranyl magnesium acetate and lead citrate. The sections were carbon coated and examined with a Phillips 201 EM scope.

Although the GABA R10B antiserum has been previously characterized [17], for control studies serial sections were incubated in $1 / 50,000$ rabbit anti-GABA serum that was preabsorbed with $10 \mu \mathrm{g} /$ $\mathrm{ml}$ of the GABA-bovine serum albumin conjugate or GABA itself for $8 \mathrm{~h}$ at $4^{\circ} \mathrm{C}$. Control sections were processed with the experimental sections.

The subcellular distribution of GABA immunoreactivity was determined and contrasted to insulin immunoreactivity by comparison of serial ultrathin sections stained individually for the two substances. In addition, the endocrine islet cells were identified according to their granular morphology as described by Lacy et al [18].

Quantitation of the GABA immunogold particle distribution within the B cell was based on randomly selected electron photomicrographs from four different experiments. The total number of gold particles was counted for each subcellular compartment and the area of the respective compartments was determined by using a Hewlett Packard digitizing tablet.

\section{Statistical analysis}

The Newman-Keuls statistical test for multiple comparisons was used to determine the level of statistically significant differences. Data are presented as the mean $\pm S E$.

\section{Results}

Electron microscopic examination of numerous tissue sections from several experiments consistently revealed GABA immunoreactivity present in the $\mathrm{B}$ cells and $\mathrm{ab}$ sent in the A and D cells (Fig. 1). Within the B cell, GABA immunoreactivity was present in the nuclear, mitochondrial and the remainder of the nongranular cytoplasmic compartment. To more clearly determine the subcellular localization of GABA in the B cell, serial sections, containing the same subcellular organelles were incubated with either guinea pig anti-insulin or rabbit anti-GABA sera and then examined. In these serial sections, insulin immunoreactivity was located in the secretion granules (Fig. 2a), and the GABA immunoreactivity was largely located in the extragranular compartments of the B cell (Fig. 2b). Control serial sections were always negative (Fig. 2 c).

Quantitation of the GABA immunogold particle distribution within the $B$ cell consisted of analyzing electron photomicrographs randomly selected from four different experiments. Within these photomicrographic records, there were 15 B cells, 5 nuclei $\left(25 \mu \mathrm{m}^{2}\right)$, 428 secretion granules $\left(32 \mu \mathrm{m}^{2}\right), 58$ mitochondria $\left(5 \mu \mathrm{m}^{2}\right)$ and the remaining cytoplasmic compartment $\left(65 \mu \mathrm{m}^{2}\right)$. A total of $127 \mu \mathrm{m}^{2}$ of the B cells were examined, and 4192 gold particles were counted (Table 1 ). The immunolocalization of GABA in the B cell was

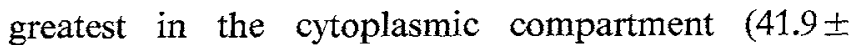
4.1 particles $/ \mu \mathrm{m}^{2}$ ), but not statistically different from the nuclear $\left(29.5 \pm 5.2\right.$ particles $\left./ \mu \mathrm{m}^{2}\right)$ and mitochondri-
Table 1. Cellular distribution of GABA immunogold

\begin{tabular}{lccc}
\hline $\begin{array}{l}\text { Cell } \\
\text { compartment }\end{array}$ & $\begin{array}{l}\text { No. of } \\
\text { components }\end{array}$ & $\begin{array}{l}\text { Total } \mu \mathrm{m}^{2} \\
\text { examined }\end{array}$ & $\begin{array}{l}\text { No. of gold } \\
\text { particles } / \mu \mathrm{m}^{2}\end{array}$ \\
\hline & & & $($ mean $\pm \mathrm{SE})$ \\
Cytoplasm & - & 65 & $41.9 \pm 4.1^{\mathrm{b}}$ \\
Secretion granules & 428 & 32 & $4.9 \pm 1.0^{\mathrm{c}}$ \\
Nuclei & 5 & 25 & $29.5 \pm 5.2^{\mathrm{b}}$ \\
Mitochondria & 58 & 5 & $29.3 \pm 6.9^{\mathrm{b}}$ \\
\hline
\end{tabular}

a 15 cells from 4 experiments; ${ }^{b}$ vs. ${ }^{c}(p<0.01)$

al compartments $\left(29.3 \pm 6.9\right.$ particles $\left./ \mu \mathrm{m}^{2}\right)$. There was very little immunoreactivity associated with the secretion granule compartment $\left(4.1 \pm 1.0\right.$ particles $\left./ \mu \mathrm{m}^{2}\right)$ $(p<0.01)$ (Table 1).

\section{Discussion}

Previous ultrastructural immunolocalization studies of the GABA system have been restricted to the central nervous system $[6,7,19-22]$. These studies of the GABA system have utilized the marker enzymes glutamate decarboxylase (GAD) and GABA transaminase (GABA-T) [19-21]. More recently, GABA itself has been studied at the ultrastructural level and was found accumulated in the neurosecretory vesicles, but also found in mitochondria, cytoplasm and nuclei $[6,7,22]$. In the present investigation, we used a post-embedding colloidal gold technique and a specific GABA antiserum to compare the distribution of GABA and insulin on serial sections of $B$ cells and to quantitate the distribution of GABA in the B cell.

Previous studies, examining the GABA system in the islet, have demonstrated that glutamate decarboxylase and GABA-transaminase are localized within the medullary cells of the islet $[3,4]$. Subsequently, we determined that GABA itself is restricted to the B cell [5]. In the present study, the ultrastructural localization of GABA in the B cell was determined. Within the B cell, GABA was found in the nucleus (primarily associated with euchromatin), mitochondria and the cytoplasm. GABA was notably deficient in the secretion granule compartment. Using data from studies on the volume density of $B$ cell subcellular particles $[23,24]$ and the particle density of the GABA immunogold obtained in this study, it is possible to estimate the distribution of GABA in the islet B cell. The results of these calculations indicate that $2.8 \%$ of the GABA is associated with secretion granules, $5.4 \%$ associated with mitochondria, $11 \%$ associated with the nucleus and $80 \%$ associated with the cytoplasmic remainder.

This study was undertaken to provide additional evidence for evaluating the proposed roles of islet $\mathrm{B}$ cell GABA. Several reports have indicated that GABA and the GABA agonist, muscimol, suppress glucose stimulated somatostatin secretion $[3,8,9]$. The present study shows that GABA, within the $\mathrm{B}$ cell, is not sequestered 
in the secretion granules. If GABA, contained in the $B$ cell, does regulate $D$ cell function, then it must be released by a nongranular mechanism independent of insulin secretion. Another proposed function of B cell GABA is the modulation of insulin synthesis. Studies on insulin biosynthesis in cultured islets indicated that gamma-vinyl GABA, a GABA-T inhibitor, stimulates insulin biosynthesis with no effect on total protein synthesis [10]. In the present study, GABA was localized in the nuclear compartment. The presence of GABA in the nucleus of the B cell may relate to the mechanism by which it stimulates insulin synthesis. Alternatively, it has been proposed that GABA may be an energy source for B cells by being metabolized through the GABA shunt [4]. Although there are presently no reports examining this hypothesis, GABA shunt enzymes (GABA-T and GAD) are located in mitochondria [25] and the cytosol [26]. In the present study GABA was found in both the mitochondria and the cytoplasm.

It is concluded from this study that GABA is localized in the nuclear and the cytoplasmic compartments, including the mitochondria, but is deficient in the secretion granules. These results support an intracellular role for GABA in the islet $B$ cell.

Acknowledgement. The authors thank Dr. Bruce Maley for providing the GABA antiserum. D.J.G. is supported by a graduate fellowship from the University of Minnesota. This work was supported in part by NIH grant AM 33655, Vegas Foundation and ADA Minnesota Affiliate.

\section{References}

1. Gerber JC, Hare TA (1979) Gamma-aminobutyric acid in peripheral tissue, with emphasis on the endocrine pancreas. Presence in two species and reduction by streptozotocin. Diabetes 28: 1073-1076

2. Okada Y, Taniguchi H, Shimada C (1976) High concentration of GABA and high glutamate decarboxylase activity in rat pancreatic islets and human insulinoma. Science 194: 620-622

3. Robbins MS, Sorenson RL, Elde RP, Schmechel DE, Oertel WH (1984) Gamma-Aminobutyric acid (GABA) inhibition of somatostatin secretion from the isolated perfused rat pancreas and immunohistochemical localization of L-glutamate decarboxylase in the islet beta cell. In: Raptis S, Rosenthal J, Gerich JE (eds) 2nd International Symposium on Somatostatin. Attempto Verlag, Tubingen, pp 165-172

4. Vincent SR, Hokfelt T, Wu J-Y, Elde RP, Morgan LM, Kimmel JR (1983) Immunohistochemical studies of the GABA system in the pancreas. Neuroendocrinology 35: 197-204

5. Garry DJ, Sorenson RL, Elde RP, Maley BE, Madsen A (1986) Immunohistochemical colocalization of GABA and insulin in B cells of rat islet. Diabetes 35: 1090-1095

6. Somogyi P, Hodgson AJ, Chubb IW, Penke B, Erdel A (1985) Antisera to gamma-aminobutyric acid. II. Immunocytochemical application to the central nervous system. J Histochem Cytochem 33: $240-248$

7. Van den Pol AN (1985) Dual ultrastructural localization of two neurotransmitter-related antigens: colloidal goldlabeled neurophysin-immunoreactive supraoptic neurons receive peroxidaselabeled glutamate decarboxylase- or goldlabeled GABA-immunoreactive synapses. J Neuroscience 5: 2940-2954

8. Robbins MS, Grouse LH, Sorenson RL, Elde RP (1981) Effect of muscimol on glucose-stimulated somatostatin and insulin release from the isolated, perfused rat pancreas. Diabetes 30:168-171
9. Taniguchi H, Yoshioka M, Ejiri K, Ishihara K, Tamagawa M, Hirose Y, Ishihara K, Utsumi M, Baba S, Okada Y (1982) Suppression of somatostatin content in pancreatic islets by GABA. In: Okada Y, Roberts E (eds) Problems in GABA research from brain to bacteria. Excerpta Medica, Amsterdam, pp 406-412

10. Taniguchi H, Okada Y, Kobayashi T, Murakami K, Baba S (1979) High concentration of gamma-aminobutyric acid and its role in $B$ cells of pancreatic islets. In: Baba S, Kaneko T, Yanihara (eds) Proinsulin, insulin, and C-peptide. Excerpta Medica, Amsterdam, pp 335-347

11. Lindall A, Steffes M, Sorenson RL (1969) Immunoassayable insulin content of subcellular fractions of rat islets. Endocrinology 85: 218-223

12. Lacy PE, Kostianovsky M (1967) Method for the isolation of intact islets of Langerhans from the rat pancreas. Diabetes 16:35-39

13. Roth J, Bendayan M, Carlemalm E, Villiger W, Garavito RM (1981) Enhancement of structural preservation and immunocytochemical staining in low temperature embedded pancreatic tissue. J Histochem Cytochem 29: 663-671

14. Bendayan M, Shore GG (1982) Immunocytochemical localization of mitochondrial proteins in rat hepatocyte. J Histochem Cytochem 30: 139-147

15. Roth I, Berger EG (1982) Immunocytochemical localization of galactosyltransferase in HeLa cells: codistribution with thiamine pyrophosphatase in trans golgi cisternae. J Cell Biol 93:223-229

16. Weaver CV, Sorenson RL, Kaung H (1986) An immunohistochemical, ultrastructural, and physiological study of pancreatic islets from copper deficient penicillamine treated rats. Diabetes 35: 13-19

17. Maley BE, Newton BW (1985) Immunohistochemistry of Gamma aminobutyric acid in the cat nucleus tractus solitarius. Brain Res 330: 364-368

18. Lacy PE, Greider MH (1972) Ultrastructural organization of mammalian islets. In: Steiner DF, Freinkel N (eds) Handbook of physiology, vol 7. Williams and Wilkins, Baltimore, pp 77-90

19. Wu J-Y (1983) Immunocytochemical identification of GABAergic neurons and pathways. In: Herta L, Kvamme E, McGeer EG, Schousboe A (eds) Glutamine, glutamate and GABA in the central nervous system. Alan R Liss, New York, pp 161-176

20. Oertle WH, Schmechel DE, Mugnaini E, Tappaz ML, Kopin IJ (1981) Immunocytochemical localization of glutamate decarboxylase in rat cerebellum with a new antiserum. Neuroscience 6: $2715-2735$

21. Kuriyama K, Roberts E, Kakefuda T (1967) Association of the gamma-aminobutyric acid system with a synaptic vesicle fraction from mouse brain. Brain Res 8: 132-152

22. Storm-Mathisen J, Leknes AK, Bore AT, Vaaland JL, Edminson P, Haug FS, Ottersen OP (1983) First visualization of glutamate and GABA in neurones by immunocytochemistry. Nature 301: 517-520

23. Hellman B (1959) The total volume of the pancreatic islet tissue at different ages of the rat. Acta Path Microbiol Scand 47: 35-50

24. Aerts L, Van Assche FA (1975) Ultrastructural changes of the endocrine pancreas of pregnant rats. Diabetologia 11: 285-289

25. Kuriyama K, Sisken B, Ito J, Simonsen DG, Haber B, Roberts E (1968) The gamma-aminobutyric acid system in the developing chick embryo cerebellum. Brain Res 11: 412-430

26. Wu J-Y, Matsuda T, Roberts E (1973) Purification and characterization of glutamate decarboxylase from mouse brain. $J$ Biol Chem 248: 3029-3034

Received: 19 August 1986

and in revised form: 15 December 1986

Dr. Robert L. Sorenson

Department of Cell Biology and Neuroanatomy

4-157 Jackson Hall

321 Church St. S.E.

University of Minnesota

Minneapolis, MN 55455

USA 